\title{
Detection of autoantibodies against reactive oxygen species modified glutamic acid decarboxylase-65 in type 1 diabetes associated complications
}

\author{
Mohd Wajid Ali Khan ${ }^{1,2^{*}}$, Kamalpreet Banga ${ }^{3}$, Subhash N Mashal ${ }^{4}$, Wahid Ali Khan ${ }^{2,5}$
}

\begin{abstract}
Background: Autoantibodies against glutamate decarboxylase-65 ( $\left.G A D_{65} A b s\right)$ are thought to be a major immunological tool involved in pathogenic autoimmunity development in various diseases. $G_{A D}{ }_{65} A b s$ are a sensitive and specific marker for type 1 diabetes (T1D). These autoantibodies can also be found in 6-10\% of patients classified with type 2 diabetes (T2D), as well as in 1-2\% of the healthy population. The latter individuals are at low risk of developing T1D because the prevalence rate of $G_{A D}{ }_{65} A b s$ is only about $0.3 \%$. It has, therefore, been suggested that the antibody binding to $G A D_{65}$ in these three different $G_{A D}{ }_{65}$ Ab-positive phenotypes differ with respect to epitope specificity. The specificity of reactive oxygen species modified $G_{A} D_{65}\left(R O S-G A D_{65}\right)$ is already well established in the T1D. However, its association in secondary complications of T1D has not yet been ascertained. Hence this study focuses on identification of autoantibodies against ROS-GAD 65 (ROS-GAD 65 Abs) and quantitative assays in T1D associated complications.

Results: From the cohort of samples, serum autoantibodies from T1D retinopathic and nephropathic patients showed high recognition of ROS-GAD 65 as compared to native $G_{A D}\left(N-G A D_{65}\right)$. Uncomplicated T1D subjects also exhibited reactivity towards ROS-GAD 65 . However, this was found to be less as compared to the binding recorded from complicated subjects. These results were further proven by competitive ELISA estimations. The apparent association constants (AAC) indicate greater affinity of lgG from retinopathic T1D patients $\left(1.90 \times 10^{-6} \mathrm{M}\right)$ followed by nephropathic $\left(1.81 \times 10^{-6} \mathrm{M}\right)$ and uncomplicated $\left(3.11 \times 10^{-7} \mathrm{M}\right)$ T1D patients for ROS-GAD 65 compared to N-GAD 65 .

Conclusion: Increased oxidative stress and blood glucose levels with extended duration of disease in complicated T1D could be responsible for the gradual formation and/or exposing cryptic epitopes on $G_{A D} 65$ that induce increased production of ROS-GAD 65 Abs. Hence regulation of ROS-GAD 65 Abs could offer novel tools for analysing and possibly treating T1D complications.
\end{abstract}

\section{Background}

In autoimmune diabetes the autoantibodies have always been important for clinical interest due to their potential role in screening, diagnosis, monitoring treatment of effectiveness and prognosis. The $\mathrm{GAD}_{65} \mathrm{Abs}$ are often considered to be an epiphenomenon resulting from the autoimmune destruction of the pancreatic beta cells in T1D. Previous studies suggest that they are involved in

\footnotetext{
* Correspondence: wajidkhan11@gmail.com

'Department of Biochemistry, Faculty of Medicine and Health Sciences -

Gomail, University of Aljabal Algharbil, Zawia-16418, Libya

Full list of author information is available at the end of the article
}

antigen processing and presentation and thus modulate the immune response [1]. Because of the high diagnostic sensitivity for autoimmune diabetes, the presence of $\mathrm{GAD}_{65} \mathrm{Ab}$ is currently used to identify subjects at high risk for the disease [2]. $\mathrm{GAD}_{65} \mathrm{Abs}$ are detected in about $60 \%$ of new-onset cases of type 1 diabetes [3], and high levels of these autoantibodies were also reported in diabetic patients with secondary complications (such as retinopathy and nephropathy), thus leading cause of blindness and renal failure $[4,5]$. The exact etiology behind these complications is not completely clear.

\section{() Biomed Central}

(c) 2011 Khan et al; licensee BioMed Central Ltd. This is an Open Access article distributed under the terms of the Creative Commons Attribution License (http://creativecommons.org/licenses/by/2.0), which permits unrestricted use, distribution, and reproduction in any medium, provided the original work is properly cited. 
In our recent study; ROS modified $\mathrm{GAD}_{65}$ was found to be more immunogenic in T1D than its native form [6]. $\mathrm{GAD}_{65} \mathrm{Abs}$ in T1D are predominantly directed at conformational epitopes located in the middle region of the molecule, whereas they also recognize linear epitopes and epitopes located in the middle, $\mathrm{COOH}$ - and $\mathrm{NH}_{2}$-terminuses $[7,8]$. Shifts in $\mathrm{GAD}_{65}$ epitopes were detected in a subgroup of newly diagnosed children within the first 12 months after disease onset [9]. Moreover, epitope spreading has gained credence as a major driver underlying autoimmunity [10].

Growing evidence suggests that ROS plays an important role in the initiation and progression of diabetes and its associated complications [11]. These increased levels of free radicals pose a direct toxic effect on $\mathrm{GAD}_{65}$ and increase its immunogenicity [6]. Specificity of autoantibodies for epitopes on $\mathrm{GAD}_{65}$ and their levels may be a better indicator of impending or actual destruction of islet $\beta$-cells and increasing complications associated with diabetes.

In the view of the above mentioned studies we hypothesized some possible link between diabetic associated complications and presence of ROS-GAD ${ }_{65} \mathrm{Abs}$. To prove this, binding characteristics of serum autoantibodies from uncomplicated and complicated (nephropathic and retinopathic) T1D patients were assessed with N-GAD 65 and ROS-GAD 65 by direct binding and competitive ELISA. The avidity of modified $\mathrm{GAD}_{65}$ was also evaluated by precipitate titration curve in different diabetic groups.

\section{Results}

ROS modification of $\mathrm{GAD}_{65}$

ROS directed modification of $\mathrm{GAD}_{65}$ studied previously by our group showed marked structural changes [6]. Khan et al., demonstrated that hyperchromicity and tryptophan specific fluorescence for modified $\mathrm{GAD}_{65}$ was found to be significantly higher than native $\mathrm{GAD}_{65}$ and the spectral analysis also showed blue shift of 10 $\mathrm{nm}$ in modified $\mathrm{GAD}_{65}$ over native $\mathrm{GAD}_{65}$. Far-UV-CD spectropolarimetry of ROS-GAD65 exhibited significant changes in secondary structural elements compared to its unmodified form decrease in $\alpha$-helix and an increase of in $\beta$-sheet, random coil and turns was observed [6].

\section{Detection of autoantibodies against N-GAD 65 and ROS- $\mathrm{GAD}_{65}$}

In a pilot study serum samples from uncomplicated and complicated T1D patients were screened for autoantibodies against $\mathrm{N}-\mathrm{GAD}_{65}\left(\mathrm{GAD}_{65} \mathrm{Abs}\right)$ and ROS-GAD 65 (ROS-GAD 65 Abs) using unmodified and ROS-modified $\mathrm{GAD}_{65}$ as antigens. From Figure 1, we observed that sera from normal human $(\mathrm{NH})$ subjects showed very low level of reactivity towards N-GAD 65 [optical density $(\mathrm{OD}) ; 0.07 \pm 0.02]$ or ROS-GAD ${ }_{65}(\mathrm{OD} ; 0.08 \pm 0.02)$.

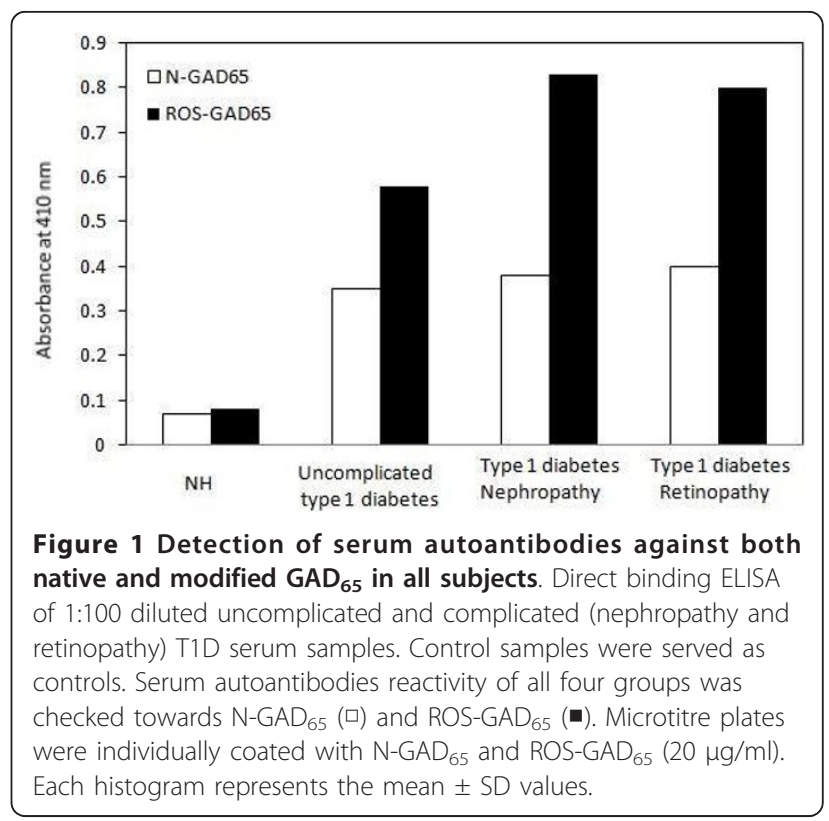

Conversely, serum autoantibodies of uncomplicated T1D patients showed significant binding with ROS$\mathrm{GAD}_{65}(\mathrm{OD} ; 0.58 \pm 0.04, p<.0001)$ as compared to $\mathrm{N}$ $\mathrm{GAD}_{65}(\mathrm{OD} ; 0.35 \pm 0.03)$. Moreover, sera from diabetic nephropathic (OD; $0.83 \pm 0.03, p<.0001)$ and diabetic retinopathic $(\mathrm{OD} ; 0.80 \pm 0.05, p<.0001)$ patients exhibited statistically higher significant differences in the binding pattern of serum autoantibodies with ROS$\mathrm{GAD}_{65}$ as compared to $\mathrm{N}-\mathrm{GAD}_{65}$ (nephropathic; $0.38 \pm$ 0.05 and retinopathic; $0.40 \pm 0.04$ ).

OD was considered as a direct measure of the concentrations of autoantibodies in the serum samples. In all the study groups there were higher levels of reactivity of modified antigen as compared to its native form. $\mathrm{NH}$ samples showed $14 \%$ increased and uncomplicated serum samples exhibited $65.7 \%$ increased reactivity towards ROS-GAD 65 as compared to N-GAD 65 . Whereas, nephropathic and retinopathic T1D complicated subjects showed an increase of $118.4 \%$ and $100 \%$ respectively, in the reactivity with modified antigen when compared with unmodified antigen.

The binding specificities of serum autoantibodies from uncomplicated and complicated (Nephropathic and retinopathic) T1D patients were evaluated by competitive ELISA using N-GAD 65 and ROS-GAD 65 as inhibitors. Significantly higher recognition of modified antigen was observed by the serum autoantibodies from nephropathic $[70.3 \pm 8.2$ mean maximum percent inhibition (MMPI)] and retinopathic patients $(74.5 \pm 6.5 \mathrm{MMPI}]$ as compared to uncomplicated T1D serum samples $(50.6 \pm 7.2 \mathrm{MMPI})$. $\mathrm{N}-\mathrm{GAD}_{65}$ exhibited no marked difference in recognition of serum IgG from both complicated [nephropathy (39.2 \pm $5.4 \mathrm{MMPI})$ and retinopathy (41.1 $\pm 5.3 \mathrm{MMPI})]$ 
and uncomplicated (35.2 $\pm 5.9 \mathrm{MMPI})$ subjects of T1D, Table 1. Normal humans showed very less or negligible percent inhibition with either of the antigens $\left[\mathrm{N}-\mathrm{GAD}_{65}\right.$ $(7.3 \pm 3.6 \mathrm{MMPI})$ and $\left.\mathrm{M}-\mathrm{GAD}_{65}(7.2 \pm 3.2 \mathrm{MMPI})\right]$.

\section{Estimation of protein bound carbonyl compounds in serum samples}

In vivo carbonyl content was considered a biomarker of oxidative stress. Oxidative stress levels were estimated for every patient of each group of T1D (Table 2). Data showed significant increase in serum protein bound carbonyl contents $(p<0.001)$ in complicated subjects as compared to uncomplicated T1D patients. Complicated subjects, T1D who had retinopathy $(3.9 \pm 0.31$ nmoles/ mg protein) exhibited higher amounts of protein bound carbonyl content as compared to nephropathic (3.4 \pm 0.28 nmoles/mg protein) T1D patients.

\section{Quantification of apparent association constant}

The amount of antigen bound to antibody was also evaluated by quantitative precipitin titration curve. IgG of uncomplicated (serum no. 11) and complicated [nephropathic (serum no. 3) and retinopathic (serum no. 6)] subjects was purified by affinity chromatography on Protein A-Agarose column. The purified IgGs were found to elute in a single symmetrical peak. Varying amounts of modified $\mathrm{GAD}_{65}(0-40 \mu \mathrm{g})$ were mixed with $100 \mu \mathrm{g}$ of patient's IgG and incubated for $2 \mathrm{~h}$ at $37^{\circ} \mathrm{C}$ and overnight at $4^{\circ} \mathrm{C}$. Microsurface adsorption-spectral correction (MSASC) technique showed the interaction of IgG with modified protein. Langmuir equation was used to estimate AAC of complicated and uncomplicated T1D samples for ROS-GAD 65 (Figure 2) and was computed to be $1.81 \times 10^{-6} \mathrm{M}$ and $1.90 \times 10^{-6} \mathrm{M}$ for T1D nephropathic and retinopathic patients respectively. Uncomplicated T1D showed $3.11 \times 10^{-7} \mathrm{M}$ AAC. A maximum of $23 \mu \mathrm{g}$ and $20 \mu \mathrm{g}$ of ROS-GAD 65 was bound to $84 \mu \mathrm{g}$ and $87 \mu \mathrm{g}$ of IgG from T1D nephropathic and retinopathic subjects respectively. However uncomplicated T1D patients exhibited $28 \mu \mathrm{g}$ of IgG bound with $76 \mu \mathrm{g}$ of ROS-GAD 65 . No appreciable differences were observed in the AACs calculated for N-GAD 65 in same above mentioned serum samples of complicated (nephropathic; $2.87 \times 10^{-7} \mathrm{M}$ and

Table 1 Inhibition of serum IgG from uncomplicated T1D, complicated T1D and control subjects towards native and modified $\mathrm{GAD}_{65}$

\begin{tabular}{|c|c|c|c|c|c|c|c|c|}
\hline \multicolumn{9}{|c|}{ Maximum percent inhibition at $20 \mu \mathrm{g} / \mathrm{ml}$} \\
\hline \multirow[t]{2}{*}{ Serum } & \multicolumn{2}{|c|}{ Uncomplicated T1D } & \multicolumn{2}{|c|}{ Nephropathic T1D } & \multicolumn{2}{|c|}{ Retinopathic T1D } & \multicolumn{2}{|c|}{ Controls } \\
\hline & $\mathrm{N}-\mathrm{GAD}_{65}$ & $M-G A D_{65}$ & $\mathrm{~N}-\mathrm{GAD}_{65}$ & $M-G A D_{65}$ & $N-G A D_{65}$ & $M-G A D_{65}$ & $\mathrm{~N}-\mathrm{GAD}_{65}$ & $M-G A D_{65}$ \\
\hline 1 & 36 & 54 & 40 & 78 & 39 & 85 & - & - \\
\hline 2 & 38 & 40 & 42 & 66 & 37 & 79 & - & 7 \\
\hline 3 & 47 & 61 & 54 & 79 & 44 & 57 & 7 & 11 \\
\hline 4 & 37 & 55 & 41 & 70 & 41 & 68 & - & - \\
\hline 5 & 43 & 49 & 48 & 66 & 32 & 65 & - & - \\
\hline 6 & 35 & 54 & 35 & 74 & 37 & 79 & - & 10 \\
\hline 7 & 40 & 60 & 44 & 56 & 43 & 76 & 10 & 7 \\
\hline 8 & 26 & 68 & 39 & 73 & 51 & 57 & - & - \\
\hline 9 & 22 & 37 & 30 & 59 & 36 & 70 & 7 & 9 \\
\hline 10 & 38 & 56 & 37 & 62 & 50 & 77 & 8 & 5 \\
\hline 11 & 45 & 63 & 42 & 57 & 40 & 70 & - & 7 \\
\hline 12 & 34 & 50 & 29 & 59 & 48 & 69 & - & - \\
\hline 13 & 46 & 55 & 37 & 76 & 50 & 79 & 5 & 9 \\
\hline 14 & 41 & 52 & 36 & 69 & 36 & 75 & - & - \\
\hline 15 & 33 & 39 & 39 & 78 & 33 & 81 & - & - \\
\hline 16 & 21 & 48 & 28 & 79 & 30 & 83 & 6 & 7 \\
\hline 17 & 19 & 41 & 26 & 69 & 28 & 78 & 8 & 6 \\
\hline 18 & 26 & 37 & 27 & 75 & 37 & 79 & 6 & 7 \\
\hline 19 & 31 & 45 & 35 & 81 & 35 & 82 & 9 & 8 \\
\hline 20 & 28 & 47 & 39 & 80 & 40 & 80 & - & - \\
\hline Mean \pm SD & $35.2 \pm 5.9$ & $50.6 \pm 7.2$ & $39.2 \pm 5.4$ & $70.3 \pm 8.2^{*}$ & $41.1 \pm 5.3$ & $74.5 \pm 6.5^{*}$ & $7.3 \pm 3.6$ & $7.2 \pm 3.7$ \\
\hline
\end{tabular}

$\mathrm{N}-\mathrm{GAD}_{65}$ and $\mathrm{M}-\mathrm{GAD}_{65}$ represents Native $\mathrm{GAD}_{65}$ and modified $\mathrm{GAD}_{65}$. $\mathrm{NH}$ represents normal humans as control.

The ELISA plates were coated with N-GAD 65 and $M-G D_{65}(20 \mu \mathrm{g} / \mathrm{ml})$. ROS-GAD 65 and N-GAD 65 were used as inhibitor.

${ }^{*} p<0.001$ vs ROS-GAD ${ }_{65}$ Abs in uncomplicated T1D. 
Table 2 Clinical and laboratory data from complicated and uncomplicated T1D patients; normal human subjects serve as controls

\begin{tabular}{|c|c|c|c|c|c|c|c|c|c|}
\hline Subjects & $\begin{array}{l}\text { Number } \\
\text { of sera }\end{array}$ & $\begin{array}{c}\text { Age } \\
\text { (years } \pm S D)\end{array}$ & $\begin{array}{c}\text { Gender } \\
(\mathrm{M}: \mathrm{F})\end{array}$ & $\begin{array}{c}\text { Smoking } \\
\text { duration } n \\
\text { (years } \pm \text { SD) }\end{array}$ & $\begin{array}{l}\text { Duration of } \\
\text { disease } \\
\text { (years } \pm S D \text { ) }\end{array}$ & $\begin{array}{l}\text { Fasting blood } \\
\text { glucose (mg/dl) }\end{array}$ & $\begin{array}{c}\mathrm{HbA}_{1 \mathrm{C}} \\
(\%)\end{array}$ & $\begin{array}{c}\text { Hyperten- } \\
\text { sion } 140 / 90 \\
(\%)\end{array}$ & $\begin{array}{c}\text { Carbonyl Content } \\
\text { (nmol/mg } \\
\text { protein) }\end{array}$ \\
\hline $\begin{array}{l}\text { Uncomplic- } \\
\text { ated T1D }\end{array}$ & 60 & $30 \pm 09$ & $37: 23$ & $8(5 \pm 3.4)$ & $09 \pm 5.6$ & $238 \pm 27^{\#}$ & $\begin{array}{c}7.9 \pm \\
0.7\end{array}$ & $36(60)$ & $3.0 \pm 0.22^{\#}$ \\
\hline $\begin{array}{l}\text { Complicated } \\
\text { T1D } \\
\text { Nephropathy }\end{array}$ & 20 & $37 \pm 11$ & $12: 8$ & $14(6 \pm 3.8)$ & $14 \pm 4.9$ & $311 \pm 21^{*}$ & $\begin{array}{l}8.8 \pm \\
0.6^{*}\end{array}$ & $17(85)$ & $3.4 \pm 0.28^{*}$ \\
\hline $\begin{array}{l}\text { Complicated } \\
\text { T1D } \\
\text { Retinopathy }\end{array}$ & 20 & $42 \pm 14$ & $11: 9$ & $17(8 \pm 3.6)$ & $17 \pm 4.3$ & $335 \pm 17^{*}$ & $\begin{array}{l}9.3 \pm \\
0.7^{*}\end{array}$ & $16(80)$ & $3.9 \pm 0.31^{*}$ \\
\hline Control & 50 & $32 \pm 8$ & $28: 22$ & - & - & $96 \pm 11.2$ & $\begin{array}{c}5.8 \pm \\
0.4\end{array}$ & $4(8)$ & $2.1 \pm 0.17$ \\
\hline
\end{tabular}

Data are means \pm SD or $\mathrm{n}$ represents number of smokers from given total respective subjects. For blood glucose estimations, blood was collected in oxalated fluoride containers and the assays were performed immediately. Hypertension is defined as sitting systolic blood pressure $\geq 140 \mathrm{mmHg}$ and/or diastolic blood pressure $\geq 90 \mathrm{mmHg}$ or the use of antihypertensive medication. Signs ${ }^{*}$ and ${ }^{\#}$ represents $p$ values $<0.001$ and $<0.05$ respectively.

retinopathic; $\left.2.73 \times 10^{-7} \mathrm{M}\right)$ and uncomplicated T1D patients $\left(2.63 \times 10^{-7} \mathrm{M}\right)$ as shown in Figure 3 .

\section{Discussion}

The levels of ROS increase many folds during T1D via formation of sorbitol by polyol pathways, regeneration of cofactors $\mathrm{NADPH}$ and $\mathrm{NAD}^{+}$by $\mathrm{NAD}(\mathrm{P}) \mathrm{H}$ oxidase and glycation reactions $[12,13]$. Long term association of proteins with high concentrations of hydrogen peroxide and free radical intermediates results in protein modification both at the amino acid and protein levels [14]. This statement is supported by our previous findings based on the structural characterization of native and ROS-GAD 65

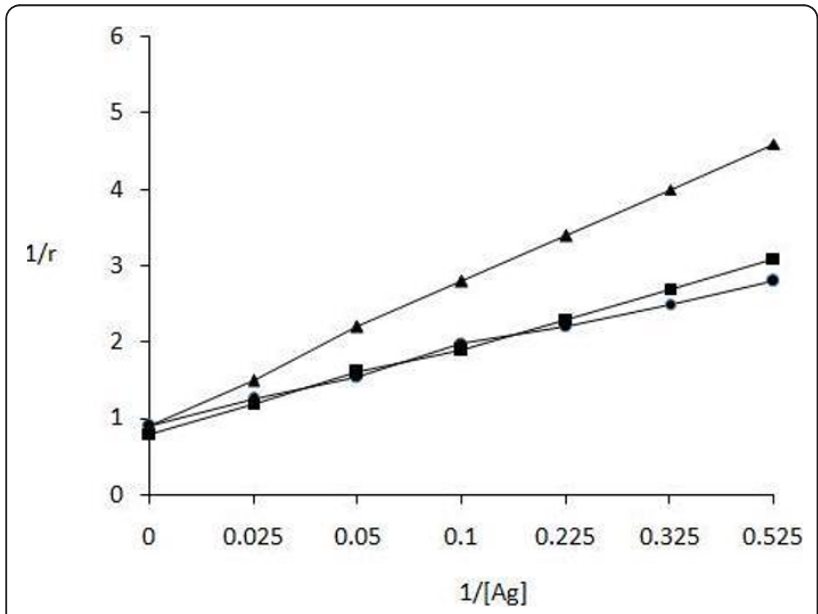

Figure 2 Determination of apparent association constants for ROS-GAD ${ }_{65}$ by Langmuir plot. Langmuir plot of reciprocal of bound antigen concentration to antibody $(1 / r)$ versus reciprocal of free antigen concentration (1/[Ag]). Antigen and antibody binding between ROS-GAD 65 and IgG isolated from nephropathic (--) serum no.3, retinopathic $(-\bullet-)$ serum no. 6 of complicated T1D and uncomplicated (-4-) (serum no. 11) T1D subjects. Each value represents mean \pm SD of four independent assays. (increased UV-absorbance and tryptophan fluorescence and changes in secondary structural elements) [6].

Significant recognition of ROS-GAD 65 by serum autoantibodies of complicated T1D patients was estimated when compared with autoantibodies from uncomplicated T1D subjects. N-GAD 65 did not show any marked differences in recognitions of circulatory autoantibodies from complicated and uncomplicated T1D subjects. The affinity of $G A D_{65} A b s$ was found to be higher in subjects who had developed T1D with neuropathy [15] or autoimmune polyendocrine disorders [16]. In control normal humans, negligible binding was observed with either of the antigens.

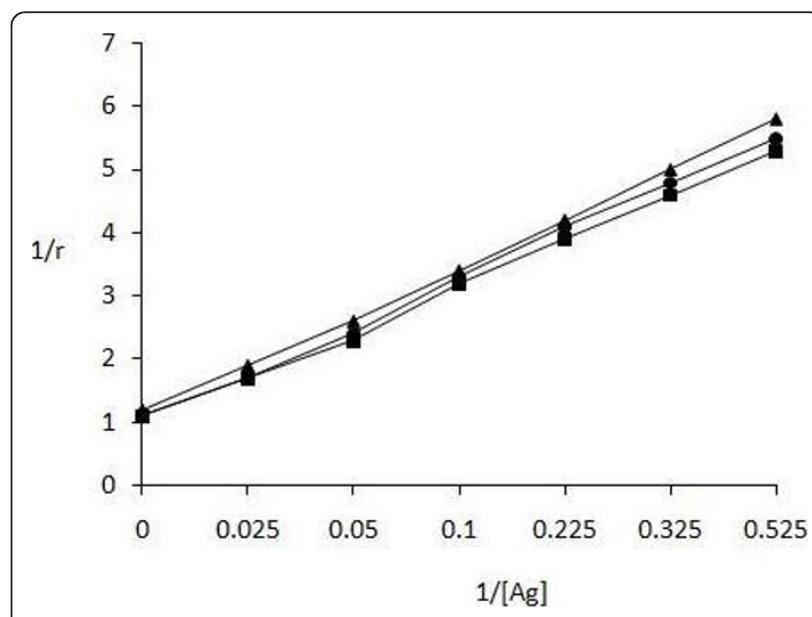

Figure 3 Determination of apparent association constant for $\mathrm{N}$ $\mathrm{GAD}_{65}$ by Langmuir plot. Langmuir plot of reciprocal of bound antigen concentration to antibody (1/r) versus reciprocal of free antigen concentration (1/[Ag]). Antigen and antibody binding between N-GAD 65 and $\operatorname{lgG}$ from nephropathic (-) serum no.3, retinopathic $(-\bullet-)$ serum no. 6 complicated T1D and uncomplicated $(-\mathbf{\Delta}-)$ (serum no. 11) T1D subjects. Each value represents mean \pm SD of four independent assays. 
From the cohort, twenty serum samples each from complicated (nephropathic and retinopathic) and uncomplicated T1D patients were selected and binding affinities of circulating autoantibodies with N-GAD 65 and ROS-GAD 65 were ascertained by competitive ELISA. Twenty serum samples from normal humans were taken under the same experimental condition as controls. A characteristic difference was observed in the pattern of inhibition ELISA assays obtained from complicated and uncomplicated T1D subjects in respect to ROS-GAD 65 antigen. This indicates that the ROS-modified $\mathrm{GAD}_{65}$ is an effective inhibitor showing substantial higher titres of circulating autoantibodies in complicated T1D subjects as compared to uncomplicated T1D. Moreover; amongst the complicated patients, retinopathic showed highest recognition for ROS $\mathrm{GAD}_{65}$ as compared to nephropathic and uncomplicated patients. Further the study also elucidates that with increased duration of disease and poor glycemic control leads to increased oxidative stress and hence the complications. The oxidative stress was further ascertained by the levels of protein bound carbonyl content in patients which is a biomarker of protein oxidation [17]. Type 1 diabetes retinopathic patients had highest carbonyl content followed by nephropathic and uncomplicated respectively. Possible this heightened state of oxidative stress leads to extensive in vivo GAD65 antigen modifications. Thus $\mathrm{GAD}_{65}$ of complicated T1D patients presents more number of epitopes that resemble in vitro ROS modified $\mathrm{GAD}_{65}$ and conceivably generates significant number of autoantibodies. $\mathrm{GAD}_{65} \mathrm{Ab}$ titers are higher and more prevalent in patients with other associated autoimmune diseases such as thyroiditis [18]. The strong dependence of conformation of protein for autoantibody recognition, blocking experiments [19] and recombinant Fab using monoclonal antibodies $[16,20]$ has been useful for determining conformational $\mathrm{GAD}_{65} \mathrm{Ab}$ epitopes.

During immune-pathophysiology significant amounts of circulating immune complexes are formed and deposited in kidneys leading to diabetic nephropathy, retinopathy and other tissues causing severe injury [21]. As we discussed in this study continuous long durations of increased levels of ROS cause increase in antigenic determinants on $\mathrm{GAD}_{65}$. So, the avidity of $\mathrm{GAD}_{65}$ became more complex and gain increased strength of binding because of interdependency of epitopes. Figure 2 and 3 clearly indicate better recognition of ROS-GAD 65 than N-GAD 65 by IgG isolated from retinopathic T1D subjects followed by nephropathic and uncomplicated T1D patient. The enhanced recognition of ROS-GAD 65 by retinopathic T1D patient IgG showed the possible participation of oxidative stress and long duration of disease as given in Table 2 that might have role in in vivo modification of $\mathrm{GAD}_{65}$ inducing the molecule to express its cryptic epitopes.

\section{Conclusion}

In conclusion, significantly high levels of circulating ROS-GAD ${ }_{65}$ Abs were detected in complicated (retinopathic and nephropathic) as compared to uncomplicated T1D patients. This risk of the disease may be exemplified due to acceleration in the formation of free radicals with gradual increase in duration of disease. This leads to conformational alterations in $\mathrm{N}$ $\mathrm{GAD}_{65}$ protein which could increase or expose cryptic epitopes. Dynamic changes in the $\mathrm{GAD}_{65} \mathrm{Abs}$ binding pattern suggest subsequent epitopes spreading with disease progression. This could be one of the etiologies of increased $\mathrm{GAD}_{65} \mathrm{Ab}$ immunogenicity that implicated in T1D complications. Measurement of these autoantibodies could be shown to be useful in assisting the prediction for the development of T1D progression/or complications. Reduction in the levels of ROS may lead to decrease in in vivo $\mathrm{GAD}_{65}$ molecules modification thus, leads to delay in the progression of complications. Hence antioxidants may play important role in the treatment.

\section{Methods}

\section{Human serum samples}

In the present study 100 T1D (60 uncomplicated and 40 complicated) and 50 control normal human (NH) subjects were investigated. All the patients were on the insulin treatment with suitable doses depending on the clinical examinations. All the serum samples of patients were collected from the laboratory of Endocrinology, Department of Medicine (J. N. Medical College and Hospital, A. M. University, Aligarh, India) and their clinical features are shown in Table 2. Approximately $20 \mathrm{ml}$ of fasting venous blood was collected from each subject. For estimation of glucose, blood was taken in oxalated fluoride containers and the assays were performed immediately. Isolated serum samples from all subjects were heated at $56^{\circ} \mathrm{C}$ for $30 \mathrm{~min}$ to deactivate complement protein and stored at $-20^{\circ} \mathrm{C}$ with sodium azide. The categories for diabetic complications were mutually exclusive. Normal humans served as controls, age and sex matched with no family history of diabetes. All groups underwent periodic examinations. All subjects gave informed consent to the analysis and the study had Ethics Committee approval. Patient classification is summarized as follows.

\section{Uncomplicated patients}

These patients $(n=60)$ have had T1D and remained free from any complications (retinopathy and nephropathy). These patients are negative proteinuria. 


\section{Nephropathic patients}

These patients $(n=20)$ had T1D and all were proteinuria positive (urinary protein excretion rates $\geq 300 \mathrm{mg}$ / $24 \mathrm{~h}$ ) in the absence of hematuria or infection in midstream urine samples.

\section{Retinopathic patients}

These patients $(n=20)$ had retinopathy defined as having more than five dots or blots per eye; hard or soft exudates and vitreous hemorrhage.

\section{Preparation of Antigen}

Human-GAD 65 (G-2126, Type II: from E. coli, Sigma, St. Louis, MO, USA) was modified with hydroxyl radicals. Briefly, solution (3.0 ml total volume) of N-GAD 65 $(100 \mathrm{mg} / \mathrm{ml})$ in $50 \mathrm{mM}$ sodium phosphate buffer, $\mathrm{pH}$ 7.4, was irradiated with $254 \mathrm{~nm}$ UV light for $30 \mathrm{~min}$ at room temperature in the presence of $10 \mathrm{mM}$ hydrogen peroxide (Genei, Bangalore, India). After modification, extensive dialysis has been was done with $50 \mathrm{mM}$ sodium phosphate buffer to remove excess hydrogen peroxide and hydroxyl radicals. Protein concentration determined by Bradford's method [22].

\section{Protein bound carbonyl groups}

Protein bound carbonyl groups from sera of different diabetic groups and $\mathrm{NH}$ subjects were analyzed according to Levine et al. [23] and the results were expressed as the number of nanomoles of carbonyl per mg of sample protein using a $\varepsilon_{379}=22,000 \mathrm{M}^{-1} \cdot \mathrm{cm}^{-1}$. Protein concentration of the samples was determined by Bradford's method [22].

\section{Elisa}

Direct binding ELISA was performed on polystyrene microtitre flat bottom plates (NUNC, Roskilde, Denmark), as described previously [6,24]. Briefly plates were coated with $100 \mu \mathrm{l}$ of respective antigen $(20 \mu \mathrm{g} / \mathrm{ml})$ for $2 \mathrm{~h}$ at room temperature and overnight at $4^{\circ} \mathrm{C}$. The plates were washed with TBS-T (20 mM Tris, $2.68 \mathrm{mM}$ $\mathrm{KCl}, 150 \mathrm{mM} \mathrm{NaCl}, \mathrm{pH}$ 7.4, containing 0.05\% Tween20) and unoccupied sites were blocked with $150 \mu \mathrm{l}$ of 1.5\% BSA in TBS (10 mM Tris, $150 \mathrm{mM} \mathrm{NaCl}, \mathrm{pH} 7.4$ ) for 4-6 $\mathrm{h}$ at room temperature. The test serum (diluted 1:100) in TBST $(100 \mu \mathrm{l}$ per well) was adsorbed for $2 \mathrm{~h}$ at room temperature and overnight at $4^{\circ} \mathrm{C}$. Bound antibodies were assayed with anti-human IgG alkaline phosphatase conjugate (Sigma, St. Louis, MO, USA) using para-nitrophenyl phosphate (Sigma, St. Louis, MO, USA) as substrate. The absorbance of each well was monitored at $410 \mathrm{~nm}$ on an automatic microplate reader (Labsystem Multiskan EX, Helsinki, Finland).

\section{Competitive ELISA}

The antigenic specificity of modified $\mathrm{GAD}_{65}$ was determined by competitive ELISA [6,24]. Varying concentrations of inhibitors $(0-20 \mu \mathrm{g} / \mathrm{ml})$ were allowed to interact with a constant amount of serum antibody (1:20 diluted serum) for $2 \mathrm{~h}$ at room temperature and overnight at $4^{\circ} \mathrm{C}$. The immune complex thus formed was incubated in the wells and the bound antibody levels were detected as in direct binding ELISA.

The percent inhibition was calculated using the formula:

$$
\text { Percent inhibition }=\left[1-\left(\mathrm{A}_{\text {inhibited }} / \mathrm{A}_{\text {uninhibited }}\right) \times 100\right]
$$

Where $\mathrm{A}_{\text {inhibited }}$ is the absorbance at $20 \mu \mathrm{g} / \mathrm{ml}$ of inhibitor concentration and $\mathrm{A}$ uninhibited the absorbance at zero inhibitor concentration.

\section{IgG isolation}

Immunoglobulin $G$ was isolated from uncomplicated and complicated T1D sera on Protein A-Sepharose CL-4B column (Genei, Bangalore, India) [25]. The homogeneity of isolated IgG was checked by $7.5 \%$ polyacrylamide gel electrophoresis.

\section{Quantitation of antigen-antibody immune complex}

One hundred micrograms of IgG was incubated with varying amounts of ROS-GAD 65 antigen in an assay volume of $500 \mu \mathrm{l}$. The mixture was incubated for $2 \mathrm{~h}$ at room temperature and overnight at $4^{\circ} \mathrm{C}$. The immune complexes were pelleted, washed twice with PBS and dissolved in $250 \mu \mathrm{l}$ of $1 \mathrm{~N} \mathrm{NaCl}$. Protein concentrations were measured by colorimetric method [22]. The binding data were analyzed for antibody affinity [26].

\section{Statistical evaluation}

The values are given as arithmetic mean \pm SD wherever indicated. Multiple comparisons were analyzed by student $\mathrm{t}$ test using SPSS16 software program and $\mathrm{p}<0.05$ was considered to be statistically significant.

\section{Acknowledgements}

Authors are thankful to the Dr. Hussain Esaa Kaal, Dean, Faculty of Medicine and Health Sciences-Algomail, University of Aljabal Algharbil, Zawia, Libya for giving valuable support during manuscript preparation. This work was supported by A. M. University, (India) authorities who provided the essential facilities for carrying out this research.

\section{Author details}

${ }^{1}$ Department of Biochemistry, Faculty of Medicine and Health Sciences Gomail, University of Aljabal Algharbil, Zawia-16418, Libya. ${ }^{2}$ Department of Biochemistry, Faculty of Medicine, J. N. Medical College, Aligarh Muslim University, Aligarh-202002, India. ${ }^{3}$ Department of Community Medicine, Faculty of Medicine and Health Sciences - Gomail, University of Aljabal Algharbil, Zawia-16418, Libya. ${ }^{4}$ Department of Pathology, Faculty of Medicine and Health Sciences - Gomail, University of Aljabal Algharbil, Zawia-16418, Libya. ${ }^{5}$ Department of Clinical Biochemistry, College of Medicine and Medical Science, King Khalid University, Abha-61421, Kingdom of Saudi Arabia.

\section{Authors' contributions}

MWAK designed and carried out all of the experiments and analysed the results. KB participated in data analyses. SNM helped in drafting the 
manuscript. WAK helped to carry out some ELISA experiments and in writing the discussion. All authors read and approved the final manuscript.

Received: 24 May 2010 Accepted: 8 March 2011

Published: 8 March 2011

\section{References}

1. Banga JP, Moore JK, Duhindan N, Madec AM, Vanendert PM, Orgiazzi J, Endl J: Modulation of antigen presentation by autoreactive $B$ cell clones specific for GAD65 from a type I diabetic patient. Clin Exp Immunol 2004, 135:74-84.

2. Falorni A, Kassi G, Murdolo G, Calcinaro F: Controversies on humoral immune markers of insulin-dependent diabetes mellitus. J Ped Endocrinol Metab 1998, 11:307-317.

3. Bonifacio E, Genovese S, Braghi S: Islet autoantibody markers in IDDM: risk assessment strategies yielding high sensitivity. Diabetol 1995, 38:816-822.

4. Jakus V, Rietbrock N: Advance glycation end-products and the progress of diabetic vascular complications. Physiol Res 2004, 53:131-142.

5. Chaturvedi N, Bendinelli S, Mangili R, Penno G, Rottiers RE, Fuller JH: Microalbuminuria in type 1 diabetes: rate, risk factors and glycemic threshold. Kidney Int 2001, 60:219-227.

6. Khan MWA, Sherwani S, Khan WA, Moinuddin, Ali R: Characterization of hydroxyl radical modified $\mathrm{GAD}_{65}$ : a potential autoantigen in type 1 diabetes. Autoimmunity 2009, 42:150-158.

7. Hampe CS, Hammerle LP, Bekris L, Ortqvist E, Kockum I, Rolandsson O, Landin-Olsson M, Torn C, Persson B, Lernmark A: Recognition of glutamic acid decarboxylase (GAD) by autoantibodies from different GAD antibody-positive phenotypes. J Clin Endocrinol Metab 2000, 85:4671-4679.

8. Bjork E, Velloso LA, Kampe O, Karlsson FA: GAD autoantibodies in IDDM, stiff-man syndrome, and autoimmune polyendocrine syndrome type I recognize different epitopes. Diabetes 1994, 43:161-165.

9. Hampe CS, Ortqvist E, Persson B, Schranz DB, Lernmark A: Glutamate decarboxylase (GAD) autoantibody epitope shift during the first year of type 1 diabetes. Horm Metab Res 1999, 31:553-557.

10. Scofield RH, Kaufman KM, Baber U, James JA, Harley JB, Kurien BT: Immunization of mice with human 60-kd Ro peptides results in epitope spreading if the peptides are highly homologous between human and mouse. Arthritis Rheum 1999, 42:1017-24.

11. Coughlan MT, Thorburn DR, Penfold SA, Laskowski A, Harcourt BE, Sourris KC, Tan AL, Fukami K, Thallas-Bonke V, Nawroth PP, Brownlee M, Bierhaus A, Cooper ME, Forbes JM: RAGE-induced cytosolic ROS promote mitochondrial superoxide generation in diabetes. J Am Soc Nephrol 2009, 20:742-52.

12. Desco MC, Asensi M, Marquez R, Valls JM, Vento M, Pallardo FV, Sastre J, Vina J: Xanthine oxidase is involved in free radical production in type 1 diabetes. Diabetes 2002, 51:1118-1124.

13. Baynes JW, Thorpe SR: Role of oxidative stress in diabetic complications: a new perspective on an old paradigm. Diabetes 1999, 48:1-9.

14. Reshmi H, Pekcetin C, Guner G: Protein sulfhydryl oxidation in short-term diabetic rabbit liver and kidney tissues. Tr J Med Sci 1998, 28:581-582.

15. Kawasaki E, Takino H, Yano M, Uotani S, Matsumoto K, Takao Y, Yamaguchi Y, Akazawa S, Nagataki S: Autoantibodies to glutamic acid decarboxylase in patients with IDDM and autoimmune thyroid disease. Diabetes 1994, 43:80-86.

16. Sohnlein P, Muller M, Syren K, Hartmann U, Bohm BO, Meinck HM, Knip M, Akerblom HK, Richter W: Epitope spreading and a varying but not disease-specific GAD65 antibody response in type I diabetes: the Childhood Diabetes in Finland Study Group. Diabetologia 2000, 43:210-217.

17. Shacter E: Quantification and significance of protein oxidation in biological samples. Drug Met Rev 2000, 32:307-26.

18. Gilliam LK, Binder KA, Banga JP, Madec AM, Ortqvist E, Kockum I, Luo D, Hampe CS: Multiplicity of the antibody response to GAD65 in type I diabetes. Clin Exp Immunol 2004, 138:337-341.

19. Padoa C, Banga JP, Madec AM, Ziegler M, Schlosser M, Ortqvist E, Kockum I, Palmer J, Rolandsson O, Binder KA, Foote J, Hampe CS: Recombinant Fab of human mAbs specific to the middle epitope of GAD65 inhibit type 1 diabetes-specific GAD65Ab. Diabetes 2003, 52:2689-2695.

20. Kawasaki E, Takino H, Yano M, Uotani S, Matsumoto K, Takao Y, Yamaguchi Y, Akazawa S, Nagataki S: Autoantibodies to glutamic acid decarboxylase in patients with IDDM and autoimmune thyroid disease. Diabetes 1994, 43:80-86.

21. Fenalti G, Hampe CS, Arafat Y, Law RHP, Banga JP, Mackay IR, Whisstock JC, Buckle AM, Rowley MJ: COOH-Terminal Clustering of autoantibody and Tcell determinants on the structure of GAD65 provide insights into the molecular basis of autoreactivity. Diabetes 2008, 57:1293-1301.

22. Bradford MM: A rapid and sensitive method for quantitation of micrograms quantity of protein utilizing the principle of protein dye binding. Anal Biochem 1976, 72:248-254

23. Levine RL, Williams J, Stadtman ER, Shacter E: Carbonyl assays for determination of oxidatively modified proteins. Methods Enzymol 1994, 233:346-357.

24. Khan WA, Habib S, Khan MWA, Alam K, Moinuddin : Enhanced binding of circulating SLE autoantibodies to catecholestrogen-copper-modifed DNA. Mol Cell Biochem 2008, 315:143-150.

25. Goding JW: Use of staphylococcal protein A as immunological reagent. J Immunol Methods 1978, 20:241-254.

26. Langmuir I: The adsorption of gases on plane surface glass, mica and platinum. J Am Chem Soc 1918, 40:1361-1403.

doi:10.1186/1471-2172-12-19

Cite this article as: Khan et al:: Detection of autoantibodies against reactive oxygen species modified glutamic acid decarboxylase-65 in type 1 diabetes associated complications. BMC Immunology 2011 12:19.

\section{Submit your next manuscript to BioMed Central and take full advantage of:}

- Convenient online submission

- Thorough peer review

- No space constraints or color figure charges

- Immediate publication on acceptance

- Inclusion in PubMed, CAS, Scopus and Google Scholar

- Research which is freely available for redistribution

Submit your manuscript at www.biomedcentral.com/submit
C Biomed Central 